\title{
Why some doctors want to defund the police
}

\author{
Cite as: CMAJ 2020 November 30;192:E1644-5. doi: 10.1503/cmaj.1095905
}

Posted on cmajnews.com on November 10, 2020

$\mathrm{M}$ edical student Semir Bulle knows what it's like to live in fear of the police. A child of Ethiopian refugees, he was carded a dozen times in one year while growing up in northwestern Ontario. Bulle says those interactions sent a message: "The police are going to be watching me, and I have to be sure I'm looking nonsuspicious, so they don't try to harass me today."

Only later, in university, Bulle realized that his white classmates had different experiences. "I was surprised to find out they weren't scared to walk by police," he says.

Now, Bulle is a co-organizer of Doctors for Defunding the Police - a group of Canadian medical trainees and health professionals who are urging governments to redistribute funding for law enforcement to social services in the wake of recent deaths in custody. According to the group, "these deadly tragedies highlight concerns around police response to individuals in distress or experiencing mental health crises and the use of lethal force against Black and Indigenous people."

Of 100 people killed by Canadian police between 2017 and 2020, most were young men, and a disproportionate number were Indigenous or Black. Too often, "the person is clearly in a mental health crisis," Bulle says. "We send the police, and [the person in distress] ends up dead."

Doctors for Defunding the Police contends that people in crisis have better outcomes interacting with non-police response teams. They also argue that funding for education, health care and other social services goes further than policing to prevent crime.

"Police are responding to problems, not preventing them," says group coorganizer Dr. Saadia Sediqzadah, a psychiatrist in Toronto. "We're falling into

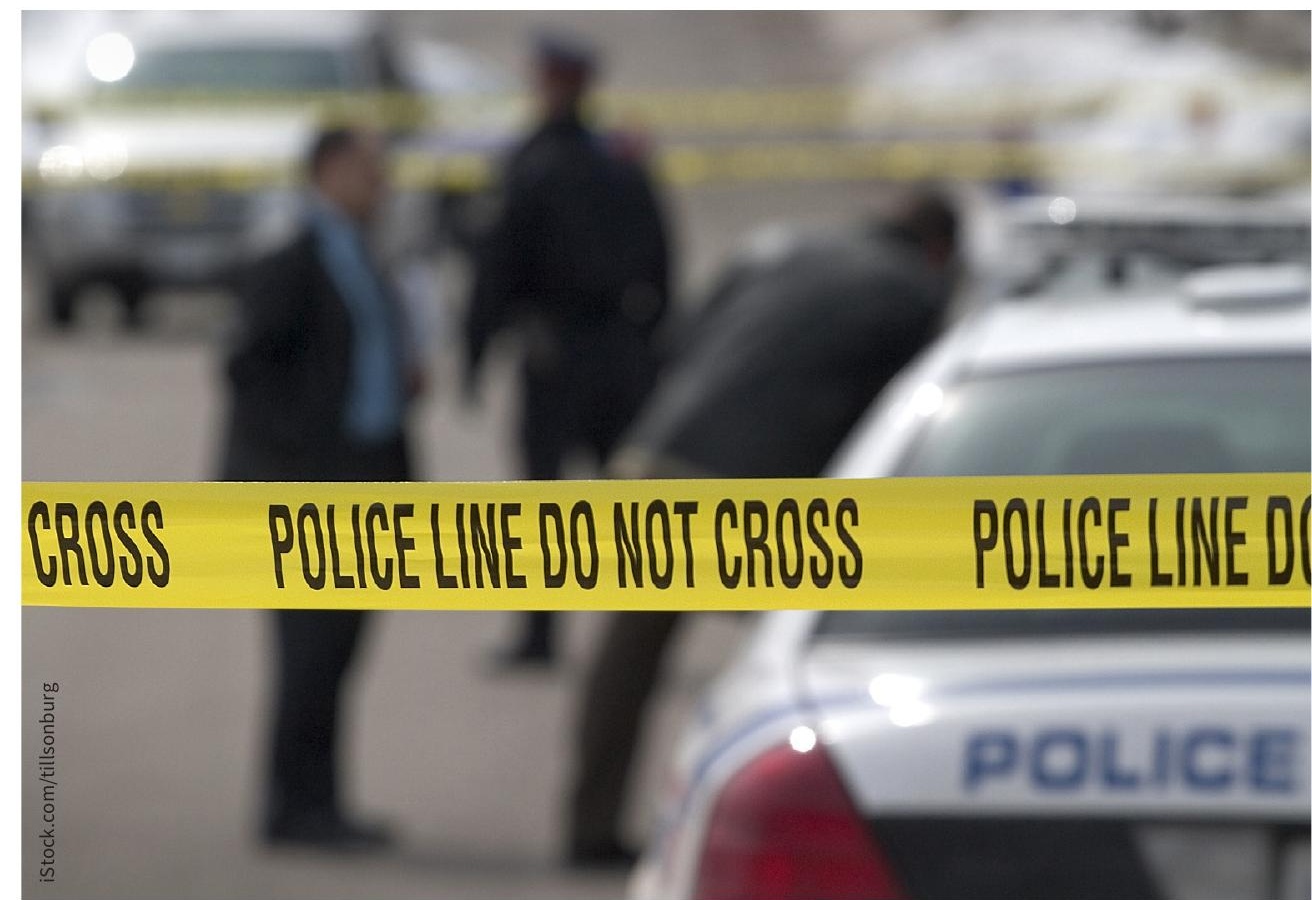

Calling the police shouldn't be the only option in mental health crises, say health advocates.

the trap of focusing on the downstream, instead of focusing on the upstream."

Sediqzadah says many racialized patients with schizophrenia and other disorders have paranoias linked to being disproportionately targeted by police. Yet, when a patient poses a risk to themselves and others in the community, her only option is to issue a "Form 1," triggering the police to apprehend the person for involuntary admission to hospital.

For any other health crisis, "it's an ambulance that will show up," Sediqzadah says. Having to involve the police in mental health crises is tantamount to "criminalizing mental illness," she says.

Earlier this year, Royal Canadian Mounted Police Commissioner Brenda Lucki told members of parliament that she agreed with calls to boost funding for mental health supports. However, she stressed that the police should remain as first responders to mental health crises. "At three o'clock in the morning when somebody's wielding a knife, and they're suffering from a mental health crisis, that is not the time to bring in mental health practitioners," Lucki told the federal public safety committee.

Police have long been the informal first responders of Canada's mental health system, mainly by default, as the expansion of community supports has not kept up with cuts to long-term psychiatric beds.

According to the Canadian Mental Health Association BC Division, nearly a third of people with serious mental illness have contact with police when trying to access mental health care for the first time. They are also more likely than other Canadians to be arrested or die in those interactions. 
Yet, most mental health crises don't require a police response, says Dr. Vicky Stergiopoulos, a clinician scientist and physician-in-chief at the Centre for Addiction and Mental Health in Toronto.

Stergiopoulos wants to see increased public funding for non-police emergency mental health responses. "The presence of police escalates the agitation, as opposed to providing the safe holding environment that someone needs to regain control of themselves," she says. "There is expertise in the mental health field on how to allow others to regain control of themselves."

She points to the Crisis Assistance Helping Out on the Streets (CAHOOTS) service in Eugene, Oregon, where health professionals respond to mental health calls instead of police. Last year, the service responded to $17 \%$ of the local 911 calls and called for police backup less than $1 \%$ of the time. According to the CAHOOTS program, the service saves an estimated $\$ 8.5$ million in public safety spending annually. Similar services exist in Sweden and the United Kingdom.

According to Stergiopoulos, the Gerstein Centre is perhaps the only $24 / 7$ non-police crisis intervention service in Canada. Located in Toronto, the centre operates a crisis hotline and dispatches staff specially trained in suicide and crisis intervention, CPR and first aid. The centre handles more than 30000 crisis calls annually, and its mobile team makes around 1600 visits a year. However, Stergiopoulos says that the mobile unit can sometimes take hours to arrive because of limited capacity.

Then, there are mobile crisis intervention teams (MCITs), which pair police and health providers in responding to mental health calls. Stergiopoulos and colleagues found that the Toronto Police's MCITs had lower rates of injuries, arrests and involuntary hospitalizations than policeonly teams. But the presence of uniformed officers can still be triggering for some people, which is why Stergiopoulos recommended that MCITs use unmarked vehicles, dress in civilian clothes and avoid using handcuffs. Toronto Police has since expanded the MCITs, but police on the teams still show up in uniform and use marked cars.

According to Connie Osborne, manager of media relations for the Toronto Police, "the Service is constantly evolving and learning more about the complex issues of mental health and how best to support those living in our communities." She adds that the department is piloting the involvement of social workers and peersupport workers to provide short-term case management after interactions with MCITs.

Some health professionals argue it would make more sense for governments to fund mental health supports directly. Police-led reforms may be wellintentioned but often end up "funnelling more money into police departments at the expense of other upstream measures," says Dr. Tharuna Abbu, a family physician in Vancouver's east side.

Police spending has been on the rise across Canada since the mid-1990s, growing faster than spending on social services in some provinces and accounting for some cities' largest budget item. For example, in Toronto and Vancouver, more money goes to policing than housing, childcare, and community programs combined.

Abbu sees patients who have posttraumatic stress disorder from previous police and incarceration experiences. Many of them live in communities that are "constantly being surveilled." Meanwhile, growth in police budgets has come at the expense of needed social supports. "As the police budget grows and grows, everything else shrinks," Abbu says.

Wendy Glauser, Toronto, Ont. 